\title{
Additional evidence of pre-Silurian high-pressure metamorphic rocks in Spitsbergen
}

\author{
YOSHIHIDE OHTA, YOSHIKUNI HIROI AND TAKAO HIRAJIMA
}

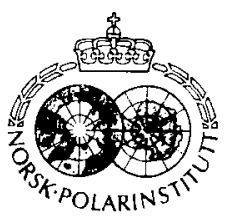

Ohta, Y., Hiroi, Y. \& Hirajima. T. 1983: Additional evidence of pre-Silurian high-pressure metamorphic rocks in Spitsbergen. Polar Research I n.s., 215-218.

It has been previously suggested that the high-pressure metamorphic rock complex of Motalafjella, central-western Spitsbergen, is older than Lower Silurian. An unconformity has been discovered at the base of a limestone which contains fossils similar to those reported as Lower Silurian from the same massif. This proves that the high-pressure metamorphics represent an older rock complex. The unconformity surface is inverted in the area, and large recumbent folds involving the Silurian Bultinden Formation have been mapped. These folds are considered to be pre-Carboniferous.

Yoshihide Ohta. Norsk Polarinstitutt, Rolfstangveien 12, 1330 Oslo Lufthaun, Norway; Yoshikuni Hiroi. Institute of Earth Science, Faculty of Education, Kanazawa University, Kanazawa, 920 Japan; Takao Hirajima, Department of Geology and Mineralogy, Faculty of Science, Kyoto University, Kyoto, 606 Japan: August 1983 (revised October 1983).

\section{Introduction}

A blueschist-eclogite complex has been reported from Motalafjella, central-western Spitsbergen (Horsfield 1972; Ohta 1978; Manby 1978; Ohta 1979). K/Ar ages have been obtained from the rocks in the range $402-475 \mathrm{Ma}$ and at $621 \mathrm{Ma}$ (Horsfield 1972). A Flyshoid succession, the Bulltinden Formation (Horsficld 1972; Hjelle et al. 1979; Harland et al. 1979), is closely connected with the complex, and fossils from the formation are considered to be Lower Silurian in age (Scrutton et al. 1976). Some pebbles of altercd schists similar to the glaucophane schists were found in boulder conglomerates of the Bulltinden Formation. and a pre-Silurian age for the high-pressure metamorphic rocks has been suggested (Horsficld 1972).

During the 1983 field survey an unconformity was discovered at the base of the limestone member of the Bulltinden Formation. and this provides concrete evidence that the high-pressure metamorphism is pre-Silurian. In this paper field observations of the unconformity are described and a preliminary re-interpretation of the geological structure of the area is presented.

\section{Geological outline of Motalafjella (Fig. 1)}

The Bulltinden Formation makes up roughly $2 / 3$ of the northcastern Motalaficlla, and consists mainly of boulder conglomcrate. black shale. grey sandstone alternations, and limestone. The remainder of the massif includes phyllitic rocks and the high-pressure metamorphic rocks of the Vestgötabreen Formation. All planar structures, both bedding and schistosity, show a monoclinical structure with a gentle curve of strikes. The mean dip is moderate to the west and southwest.

A $10-20 \mathrm{~m}$ thick limestone member of the Bulltinden For mation crosses the massif from NW to SE. The boulder conglomerate changes greatly in thickness, and the shale contains several limestone Icnses. most of which are fossiliferous.

The Vestgötabreen Formation consists of two units: a lower unit of mainly green and black phyllites with subordinate amounts of meta-basic rocks (partly showing pillow structure), quartzite, dolomitic rocks and serpentinitc, and an upper unit of mainly high-pressure metamorphic rocks and schistose limestone with a small amount of chert. The phyllites of the lower unit and the micaceous schists of the upper unit have very strong diaphtoritic cleavages.

\section{Description of the unconformity}

The unconformity has been observed clearly at two localities ( $\mathrm{A}$ and $\mathrm{B}$ in Fig. 1) and supporting evidence has been found at several other localitics (C-G in Fig. 1).

\section{Locality A. (Fig. 2)}

An about $20 \mathrm{~m}$ thick, dark grcy limestone bed of the Bulltinden Formation forms a vertical cliff here and is overlain by a dolomitic layer with a characteristic brown, weathered colour. The lower surface of the dolomitic layer has a strongly weathered appearance and is brecciated into angular-subangular blocks, the interstices of which are filled with conglomeratic grey limestone. The limestone is conglomeratic for $3-5 \mathrm{~m}$ from its structural upper surface. The clast population includes subangular-rounded blocks and pebbles. up to $20 \mathrm{~cm}$, of mainly dolomitic rocks and subordinate numbers of quartzitc, green phyllite, schistose limestone and scrpentinite, all components derived from the Vestgötabreen Formation. The matrix is dense, grey limestone and contains gastropods similar to those reported by Scrutton et al. (1976). Fossil-bearing limestone pebbles are often found in the boulder conglomerate structurally underlying the limestone. A large recumbent syncline crest can be clearly seen on the eastern cliff in the conglomerate. These observations imply that the limestone has an uncomformity at its stratigraphic base, although the whole succession is now overturned. 


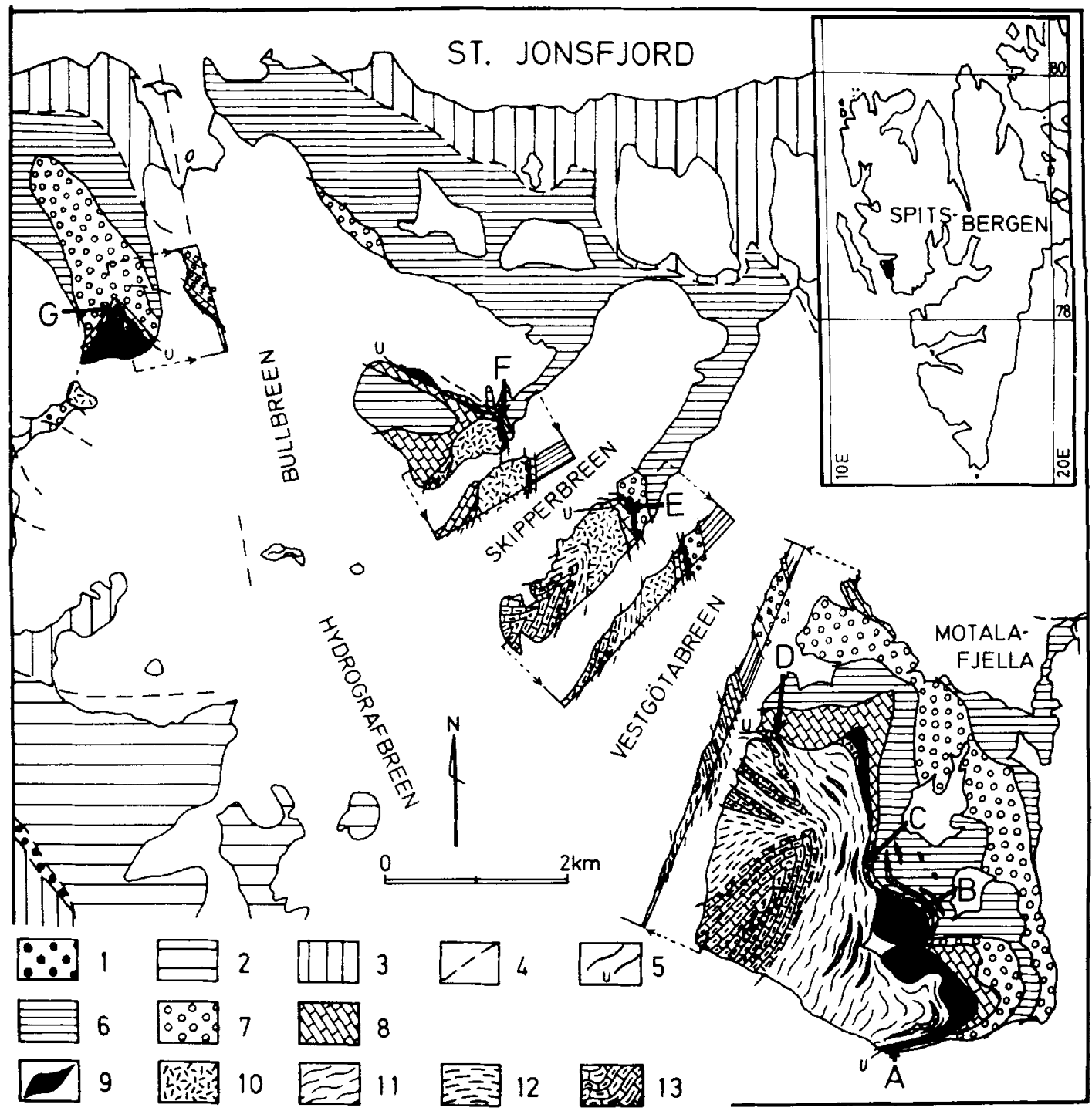

Hig. I. Geotogical map of Motalatjella and adjacent area with sthematic profiles. \&. Carhoniferous. 2. Lipper Hecla Hoek rocks. excluding the Bulltinden Formation, 3. Middle Hecla Hock rocks. 4. fault. 5. lithologic toundaries, $u=$ unconformity. Bullinden Formation. 6, shate-sandwe alternation. - houlder conglomerate. 8. limestone. Vestgörabreen formation, lower tunt: 9 . dolomitic

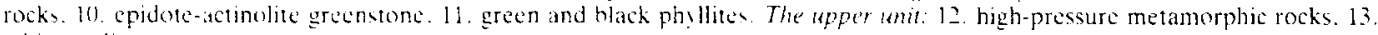
schistose limestone

\section{Locality $B$}

The wntact hetween the limestone and the dolomitic rock is exposed discontinueusly; the contiat surtace dips $10-2 l^{*}$ to the west. The limestone is conglomeratic for $2-3 \mathrm{~m}$ from the contact and has subangular to well rounded blocks and pebbles of dolomutic rocks which structurally overlie the limestone. Gatsunows have been found within the conglomeratic rocks in the northern part and sonc cross-laminated beds are totall composed of fragments of gastropods. cephalopods. and trilobites in the southern part. Thin lilms of grey limestone penetrate along joint planes of the dolomitic rock.

\section{Other localities}

The grey limestone underlics a meta-basic rock of the Vestgotabreen formation at Locality $\mathrm{C}$. The limestone contains some sandy and conglomeratic layers near the contact. and the contact surface does not show any trace of slip. The precise 


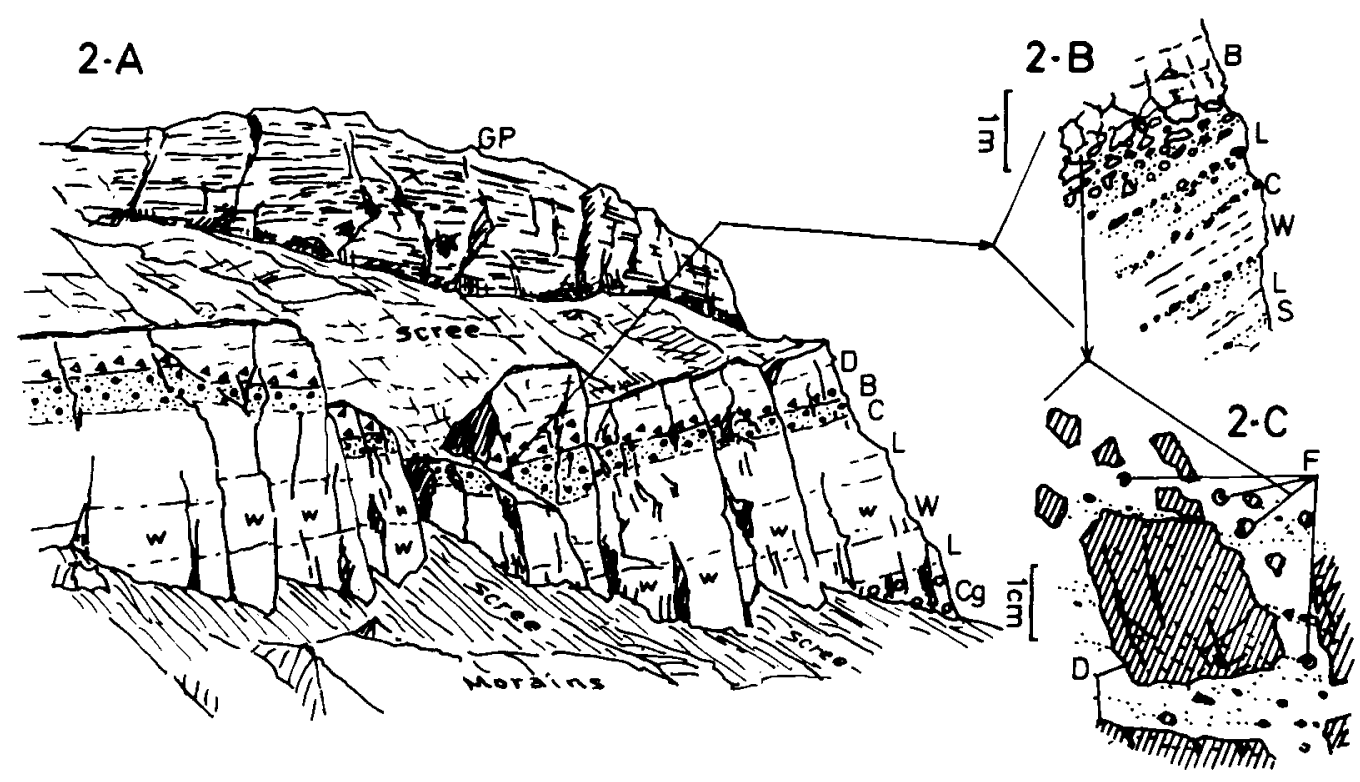

Fig. 2. Sketches of the unconformity at Locality A (after photographs). A: GP - green phyllite, D-massive dolomitic rock. $\mathrm{B}$ - brecciated and brown-weathered dolomitic rock, C - conglomeratic grey limestone, L-grey limestone, W-- white limestone, $\mathrm{Cg}$ - boulder conglomerate. $\mathrm{B}$ : Contact between the brecciated dolomitic rock and the conglomeratic limestone. $\mathrm{S}-$ sandy limestone. C: Fossils occurring in the brecciated dolomitic rock. F-gastropods. D - dolomitic rock block.

contact is not exposed at Locality D. but many scree blocks of grcy limestone contain subangular blocks and rounded pebbles of quartzite, green phyllite and dolomitic rock.

On the ridge south of Skipperbreen (Locality E). the grey limcstone underlies an epidote-actinolite greenstone of the Vestgötabreen Formation without any slip plane. Thin layers of green and white limestone, each layer less than $10 \mathrm{~cm}$ thick. form a banded structure near the contact for less than $5 \mathrm{~m}$. A stock-like epidote-actinolite greenstone is enclosed by the grey limestone on the northern ridge of Skipperbreen (Locality F). The limestone overlies the greenstones and high-pressure metamorphic rocks in the central and western part, showing banded structure as in Locality $E$, while a fault cuts the eastern part and the limestone is in contact with a dolomitic rock without signs of movement. Thus, an overturned anticline is exposed here, although being cut by the fault. The grey limestone underlies a brown dolomitic layer and greenstones on the southern slope of Bulltinden (Locality G), without slip. The conglomerate layers structurally below the limestone show overturned cross-bedding and grading.

\section{Summary}

All observations described above. despite the complexity of the folding, prove that the grey limestone member of the Bulltinden Formation formerly rested unconformably on various rocks of the Vestgötabreen Formation. This is direct evidence that the high-pressure metamorphic rocks of the Vestgötabreen Formation are older than the Silurian Bulltinden Formation.

Large recumbent folds involving the Bulltinden Formation are obvious. The Hecla Hoek rocks contain nearly isoclinical folds with sub-vertical axial planes, and are unconformably covered by Lower Carboniferous sandstone on both northern and southern sides of Eidembukta, about $5 \mathrm{~km}$ west and southwest of the present area. Isoclinical folds with similar style and axial direction occur in the Carboniferous rocks along the eastern margin of the Tertiary graben of Forlandsudet, $5 \mathrm{~km}$ northwest of the present area, but they have different dimensions from the above mentioned ones. Accordingly, these large recumbent folds developed in the Hecla Hoek rocks are most likely older than Carboniferous.

Acknowledgement. - This is the first report from the co-operation project between Norsk Polarinstitutt and Kyoto University, Japan (represented by Prof. Shohei Banno). The Japanese participants were financed by the Polar Research Committee of Kyoikusha Co. Ltd., Tokyo.

\section{References}

Harland, W. B., Horsfield. W. T., Manty, G. M. \& Morris A. P. 1979: An outline pre-Carboniferous stratigraphy of central western Spitsbergen. Nor. Polarinst. Skr. No. 167, 119-144.

Hjclle. A., Ohta, Y. \& Winsnes T. S. 1979: Hecla Hoek rocks of Oscar II Land and Prins Karls Forland, Svalbard. Nor. Polarinst. Skr. No. 167, 145-169.

Horsfield, W. T. 1972: Glaucophane schists of Caledonian age from Spitsbergen. Geol. Mag. 109(1), 29-36.

Manby, G. M. 1978: Aspect of Caledonian metamorphism in central western Svalbard with particular reference to the 


\section{Yoshihide Ohta et al.}

glaucophane schists of Oscar II Land. Polarforschung 48 (1/2). 92-102.

Ohta. Y. 1978: Caledonian metamorphism in Svalbard, with some remarks on the basement. Polarforschung 48 (1/2). $78-91$.
Ohta. Y. 1979: Blue schists from Motalfjella, western Spitsbergen. Nor. Polarinst. Skr. No. 167, 171-217.

Scrutton. C. T.. Horsficld. W. T. \& Harland, W. B. 1976: Silurian fossils from western Spitsbergen. Geol. Mag. 103 (6), 519-523. 